\title{
Comparison of the voluntary intake by lactating cows of two maize silages with different in situ dry matter degradability
}

\author{
Sandrine F. Valentin ${ }^{\mathrm{a}, \mathrm{b} *}$, J. Michael Forbes ${ }^{\mathrm{c}}$, Philippe Lescoat ${ }^{\mathrm{d}}$ \\ a Laboratoire Inra-INAPG de nutrition et alimentation, 16, rue Claude-Bernard, \\ 75231 Paris cedex 05, France \\ ' 'L'Alliance Élevage (Limagrain, Rhône-Poulenc), 55, avenue René-Cassin, \\ 69337 Lyon cedex 09, France \\ ${ }^{c}$ Department of Animal Physiology and Nutrition, University of Leeds, LS 29 JT Leeds, UK \\ ¿École supérieure d'agriculture d'Angers, BP 748, 49007 Angers, France
}

(Received 5 June 1998; accepted 25 November 1998)

\begin{abstract}
The relationship between dry matter degradability of two maize silages measured in situ and dry matter intake, milk yield, milk composition and weight gain was studied in a changeover experiment with 20 dairy cows. The animals were fed a balanced diet based on maize silage and concentrate with the same quantities of concentrate given with both silages. The two maize silages had equal levels of dry matter but were different in their neutral detergent fibre (NDF) levels (473 and $\left.414 \mathrm{~g} \cdot \mathrm{kg}^{-1}\right)$ and dry matter degradability values measured in situ over $48 \mathrm{~h}(53.9$ and $57.6 \%)$. The dry matter intake of the low-NDF, highly degradable silage was significantly higher than that of the high-NDF, low degradable material $\left(12.8 \mathrm{vs} .13 .5 \mathrm{~kg} \mathrm{DM} \cdot \mathrm{d}^{-1}\right)$ but no significant difference was observed for milk yield, fat protein and lactose milk content, milk lactose or weight gain between the two silages (23.7 vs. $23.4 \mathrm{~kg} \cdot \mathrm{d}^{-1}, 41.2$ vs. $41.4 \mathrm{~g} \cdot \mathrm{kg}^{-1}, 31.6$ vs. $31.6 \mathrm{~g} \cdot \mathrm{kg}^{-1}, 46.5$ vs. $46.2 \mathrm{~g} \cdot \mathrm{kg}^{-1}$ and 498 vs. $515 \mathrm{~g} \cdot \mathrm{d}^{-1}$ for, respectively, high- and low-NDF content maize silage). Although higher intake was linked to better dry matter degradability of maize silage, there was no effect on production, probably because of the late stage of lactation of the cows used in this experiment. (C) Elsevier / Inra)
\end{abstract}

dairy cows / maize silage / feed intake / dry matter degradability

Résumé - Comparaison de l'ingestion de deux ensilages de maïs avec des dégradabilités de la matière sèche différentes par des vaches laitières. $L$ 'influence de la dégradabilité de la matière sèche de deux ensilages de maïs mesurée in situ sur la quantité de matière sèche d'ensilage ingérée, la

* Correspondence and reprints.

Rhône-Poulenc nutrition animale, Sce R \& D, 03600 Commentry, France

Tel.: (33) 04702870 00; fax: (33) 04702871 55; e-mail: sandrine.valentin@ @rhone-poulenc.com 
production de lait, sa composition et le gain de poids a été étudiée dans un essai en inversion avec 20 vaches laitières. Les animaux recevaient une ration complète à base d'ensilage de maïs et de concentré. L'apport de concentré était le même pour les deux lots. Les deux ensilages de maïs avaient des teneurs en matière sèche sensiblement égales mais différaient par leurs teneurs en NDF et leurs valeurs de dégradabilité de la matière sèche mesurée sur 48 h $(53,9$ et $57,6 \%)$. Ils ont montré une différence hautement significative pour les valeurs de consommation (12.8 vs. $13.5 \mathrm{kgMS} \cdot \mathrm{j}^{-1}$ pour respectivement l'ensilage de maïs à hautes et basses teneurs en NDF). La production de lait, le taux butyreux, le taux protéique, le taux de lactose ou le gain de poids n'ont pas été significativement différents entre les deux ensilages (23,7 vs. $23,4 \mathrm{~kg} \cdot \mathrm{j}^{-1} ; 41,3$ vs. $41,4 \mathrm{~g} \cdot \mathrm{kg}^{-1} ; 31,6$ vs. $31,6 \mathrm{~g} \cdot \mathrm{kg}^{-1} ; 46,5$ vs. $46,3 \mathrm{~g} \cdot \mathrm{kg}^{-1}$ et 498 vs. $515 \mathrm{~g} \cdot \mathrm{j}^{-1}$ pour respectivement des teneurs hautes et basses en NDF). Un niveau d'ingestion plus élevé a été relié à une dégradabilité plus importante de la matière sèche de l'ensilage de maïs. Mais, il n'a pas été possible de mettre en évidence un effet de l'augmentation de l'ingestion de l'ensilage de maïs sur la production et la composition du lait probablement en raison du stade de lactation tardif des animaux sur lesquels ont été effectuées les mesures. (@ Elsevier / Inra)

vache laitière / ensilage de maïs / ingestion / dégradabilité de la matière sèche

\section{INTRODUCTION}

Maize silage plays a key role in the feeding of ruminant farm animals. This forage is easy to grow and conserve, and possesses high and relatively constant energetic values while the relatively low level of protein is easily corrected by supplementation with high protein concentrate. Variation in nutritive value and voluntary intake should have a major effect on milk production and thus exert a large influence on profitability. It is therefore important to have precise knowledge of the energy and protein values and of the potential intake of this type of forage. Several works attempted to predict potential intake from feed characteristics. Significant negative correlations of neutral detergent fibre (NDF) and voluntary dry matter intake (DMI) have been reported in subsequent studies with sheep and/or cattle [14, $17,23]$.

To predict intake, most researchers use rumen degradability and digestibility in the whole digestive tract. On the one hand, degradability is measured in rumen cannulated animals in which the samples to be studied are placed in nylon bags incubated in the rumen and the rate of disappearance is used to calculate an overall value for degradability $[15,16,18]$. These measures of degradability can then be used to predict potential intake by means of established regression equations $[4,10]$. This relationship is to be expected as the faster food material is broken down into small particles the faster it can leave the rumen, making place for more food to be ingested. Therefore, a more rapidly degradable forage has a lower fill value than a similar one with slower degradability.

Digestibility, on the other hand, is a measure of disappearance from the whole digestive tract and therefore does not give a clear picture of the rumen degradation. Digestibility can be measured by faecal collection from sheep or lactating cows, or estimated by incubation of food samples with rumen fluid [20], enzymes [1] or gas production [13].

The aim of this work is to see how differences in dry matter (DM) degradability measured in situ affect food intake, milk production and milk composition by cows fed on two maize silages. 


\section{MATERIALS AND METHODS}

\subsection{Silage characteristics}

The two maize hybrids used in the experiment were Cracotte and DEA harvested at the same stage of maturity. They were grown in the same field with the same agronomic treatments, including irrigation. In order to achieve a similar DM content for the two silages, Cracotte was harvested 129 days after sowing and DEA after 119 days. The two silages had already been shown to have consistent differences in degradability in three successive years (L'Alliance Élevage, unpublished values).

\subsection{Experimental design}

Silages made from the two hybrids were compared in a changeover experiment in which half of the cows were given DEA in the first period and the other half were given Cracotte. Each of the two experimental periods consisted of 15 days of adaptation period followed by a 28-days measurement period.

\subsection{Animals}

Twenty Holstein-Friesian lactating cows including eight in the first lactation were allocated to two groups balanced according to stage of lactation and pregnancy, weight at calving, milk production and food intake during the first 84 days of the current lactation.
All animals were introduced to the first treatment on the same date at which time they were at least in the 14th week of lactation.

Table I shows the characteristics of the two groups.

\subsection{Feeding and treatment}

The cows were tethered with individual access to feed and water. They were given maize silage ad libitum, which was offered twice per day and $200 \mathrm{~g}$ of sodium bicarbonate per day were added on top of the silage.

In addition, a fixed amount of $4.03 \mathrm{~kg} \mathrm{DM}$ of concentrate was dispensed automatically in three portions per day and $0.51 \mathrm{~kg} \mathrm{DM}$ of soybean meal twice per day. The morning allocation of concentrate was accompanied by $200 \mathrm{~g}$ of a mineral/vitamin premix and $12 \mathrm{~g}$ of protected methionine.

\subsection{Variables measured}

Offered and refused quantities of forage and concentrate were measured individually every day of the week. Chemical analysis of each silage (DM, ash, crude protein, starch, cell walls) was made on an average sample obtained from daily sampling during the experimental periods. For concentrates, a chemical analysis was carried out on a composite sample of each concentrate obtained at delivery.

Milk yield was measured for each animal at each milking. Milk composition was measured

Table I. Characteristics of each group.

\begin{tabular}{lcc}
\hline & $\begin{array}{c}\text { Groupe 1 } \\
\text { Means (SD) }\end{array}$ & $\begin{array}{c}\text { Groupe 2 } \\
\text { Means (SD) }\end{array}$ \\
\hline Days of lactation' & $158.3(36.2)$ & $161.8(26.4)$ \\
Days of pregnancy' & $62.8(34.3)$ & $72.3(26.6)$ \\
Weight in calving $(\mathrm{kg})$ & $646.9(84.3)$ & $655.3(72.6)$ \\
Number of lactation & $2.5(1.8)$ & $2.7(1.6)$ \\
Milk yield $\left(\mathrm{kg} \cdot \mathrm{d}^{-1}\right)$ & $33.9(5.1)$ & $35(4.7)$ \\
Fat content $\left(\mathrm{g} \cdot \mathrm{kg}^{-1}\right)$ & $39.4(3.8)$ & $39.8(4.8)$ \\
Protein content $\left(\mathrm{g} \cdot \mathrm{kg}^{-1}\right)$ & $29.4(1.8)$ & $29.5(2.2)$ \\
DMI $^{2}\left(\mathrm{~kg} \cdot \mathrm{d}^{-1}\right)$ & $16.8(2.2)$ & $17.4(2.2)$ \\
\hline
\end{tabular}

1 At the beginning of the first experimental period; ${ }^{2}$ feed intake during the first 84 days of lactation; SD: standard deviation; DMI: dry matter intake. 
individually for six successive milkings for every two last weeks of each experimental period.

Cows were weighed on two successive days every second week from the 1 st day of the experimental period.

DM degradability of each silage was measured by the in situ methodology on part of the composite sample which was used for chemical analysis. This methodology of DM degradability of each dried and ground maize silage was described by Valentin et al. [22].

\subsection{Statistical analysis}

The individual means for each period were subjected to the general linear model of analysis of variance [19] for effects of treatment, experimental period and animal. The following model was used: $Y_{i j k l}=\mu+C_{i}+P_{j}+T_{k}+\mathrm{E}_{\mathrm{ijk} \mathrm{k}}$, where $\mu$ was the overall mean; $C_{i}, P_{i}, T_{k}$ were the effects of cow, period and treatment, respectively; and $E_{i j k l}$ was the error term. When treatment differed
$(P<0.05)$, comparisons between treatments were made using the least squares difference test.

No statistical analysis was performed on the values for DM degradability in view of the absence of replicate measurements.

\section{RESULTS}

\subsection{Nutritional values and degradability of maize silages}

Table II gives the chemical composition, nutritional value of each diet constituent and DM degradability for each silage. The values for DM and starch were very similar. However, levels of nitrogen were higher for DEA than for Cracotte ( 92 vs. $80 \mathrm{~g} \cdot \mathrm{kg}^{-1}$ ). Cell walls were higher for DEA than Cracotte. In situ DM degradability was higher for Cracotte $(57.6 \%)$ than for DEA (53.9 $\%)$.

Table II. Nutritional composition of each diet constituent and degradability values of each maize silage.

Silage DEA Silage Cracotte Concentrate' Soybean meal

\begin{tabular}{lcccc}
\hline DM (\%) & 29.0 & 30.8 & 89.4 & 86.3 \\
Chemical compostion $\left(\mathrm{g} \cdot \mathrm{kg}^{-1} \mathrm{DM}\right)$ & & & & \\
$\quad$ Ash & 47 & 40 & 59 & 68 \\
Crude protein & 92 & 80 & 241 & 545 \\
Starch & 295 & 293 & $\mathrm{NA}$ & $\mathrm{NA}$ \\
Fibre & 257 & 220 & 84 & 70 \\
NDF & 473 & 414 & 219 & 212 \\
ADF & 277 & 215 & 108 & 89 \\
Lignin & 32 & 29 & 26 & 18 \\
Nutritional value $\left(\mathrm{g} \cdot \mathrm{kg}^{-1} \mathrm{DM}\right)$ & & & & \\
UFL & 0.89 & 0.91 & 1.06 & 1.16 \\
PDIN (g) & 54 & 48 & 176 & 330 \\
PDIE (g) & 68 & 69 & 172 & 230 \\
In situ degradability (\%) & & & & \\
DM degradability & 53.9 & 57.6 & NA & NA \\
\hline
\end{tabular}

UFL: net energy value for milk production [9]; PDIN: digestible proteins in the small intestine when nitrogen is lirniting in diet [9]; PDIE: digestible proteins in the small intestine when energy is limiting in diet [9]; dry matter (DM) degradability value obtained with the model of Kristensen et al. [11]; NA: not available; ' Concentrate composition (\% DM): wheat 20 , barley 20 , dehydrated sugar beet pulp 23.1, molasses 5.2 , urea 0.5 , animal fat 4.8 , salt 1 , sodium bicarbonate 0.01 , soybean meal 12.7 , protected soybean meal $12 \%$. 


\subsection{Intake}

Table III gives the nutritional value and the animal performance for each diet.

The level of DM intake varied according to maize used for ensilage, there being a highly significant difference in favour of Cracotte (diet 2). The difference between the two maize silages is $650 \mathrm{~g} \mathrm{DM} \cdot \mathrm{d}^{-1}$. Energy intakes (16.6 and 16.9 UFL. $\mathrm{d}^{-1}$ for diet 1 and $2, P<0.05)$ and protein intakes (1 572 and $1526 \mathrm{~g} \cdot \mathrm{d}^{-1}$ for PDIN values, $P<0.001,1684$ and $1742 \mathrm{~g} \cdot \mathrm{d}^{-1}$ for PDIE values, $P<0.001$, for diets 1 and 2 ) were significantly different according to treatment.

\subsection{Milk yield and composition}

There was no significant effect of treatment on the yield, $4 \%$ fat-corrected yield of milk, nor was there any effect on milk fat and protein content or lactose concentration in milk.

\subsection{Weight gain}

There was no significant difference in weight gain over the 4-week treatment period, even if this gain was slightly higher for Cracotte than DEA (respectively, 515 and $498 \mathrm{~g} \cdot \mathrm{d}^{-1}$ ).

\subsection{Requirements in energy and nitrogen of dairy cows}

Requirements included requirement for maintenance, milk production and milk content, energy and nitrogen quantities supplied by the diet. Energetic requirements were

Table III. Effect of maize hybrid on feed intake, milk yield, milk content and weight gain.

\begin{tabular}{|c|c|c|c|c|}
\hline Hybrid & $\begin{array}{l}\text { Diet } 1 \\
\text { DEA }\end{array}$ & $\begin{array}{c}\text { Diet } 2 \\
\text { Cracotte }\end{array}$ & $\begin{array}{l}\text { Signifiance } \\
\text { Level (P) }\end{array}$ & $\mathrm{SE}$ \\
\hline DMI maize silage $\left(\mathrm{kg} \cdot \mathrm{d}^{-1}\right)$ & 12.8 & 13.5 & $<0.001$ & 0.19 \\
\hline DMI total concentrate $\left(\mathrm{kg} \cdot \mathrm{d}^{-1}\right)$ & 4.5 & 4.5 & NS & 0.03 \\
\hline Total DMI $\left(\mathrm{kg} \cdot \mathrm{d}^{-1}\right)$ & 17.4 & 18.0 & $<0.001$ & 0.20 \\
\hline NDF intake with MS $\left(\mathrm{kg} \cdot \mathrm{d}^{-1}\right)$ & 6.1 & 5.6 & $<0.001$ & 0.17 \\
\hline NDF intake with total diet $\left(\mathrm{kg} \cdot \mathrm{d}^{-1}\right)$ & 7.1 & 6.6 & $<0.001$ & 0.17 \\
\hline UFL fed with MS $\left(\mathrm{g} \cdot \mathrm{d}^{-1}\right)$ & 11.4 & 12.3 & $<0.05$ & 0.40 \\
\hline PDIN fed with MS $\left(\mathrm{g} \cdot \mathrm{d}^{-1}\right)$ & 693 & 647 & $<0.001$ & 19.9 \\
\hline PDIE fed with MS $\left(\mathrm{g} \cdot \mathrm{d}^{-1}\right)$ & 873 & 930 & $<0.001$ & 30.5 \\
\hline Total UFL fed $\left(\mathrm{g} \cdot \mathrm{d}^{-1}\right)$ & 16.6 & 16.9 & $<0.05$ & 0.39 \\
\hline Total PDIN fed $\left(\mathrm{g} \cdot \mathrm{d}^{-1}\right)$ & 1572 & 1526 & $<0.001$ & 22.6 \\
\hline Total PDIE fed $\left(\mathrm{g} \cdot \mathrm{d}^{-1}\right)$ & 1684 & 1742 & $<0.001$ & 32.3 \\
\hline Milk yield $\left(\mathrm{kg} \cdot \mathrm{d}^{-1}\right)$ & 23.7 & 23.4 & NS & 1.23 \\
\hline Corrected milk $\left(\mathrm{kg} \cdot \mathrm{d}^{-1}\right)$ & 24.1 & 23.9 & NS & 5.70 \\
\hline Fat content $\left(\mathrm{g} \cdot \mathrm{kg}^{-1}\right)$ & 41.3 & 41.4 & NS & 2.57 \\
\hline Protein content $\left(\mathrm{g} \cdot \mathrm{kg}^{-1}\right)$ & 31.6 & 31.6 & NS & 1.37 \\
\hline Lactose content $\left(\mathrm{g} \cdot \mathrm{kg}^{-1}\right)$ & 46.5 & 46.3 & NS & 0.22 \\
\hline Weight gain $\left(g \cdot d^{-1}\right)$ & 498 & 515 & NS & 566 \\
\hline
\end{tabular}

MS: maize silage; SE: standard error; DMI: dry matter intake; UFL: net energy value for milk production [9]; PDIN: digestible proteins in the small intestine when nitrogen is limiting in diet [9]; PDIE: digestible proteins in the small intestine when energy is limiting in diet [9]; NS: not significant. 
largely covered by the two diets ( $107 \%$ for DEA and $103 \%$ for Cracotte) regarding the French UFL system. However, nitrogen requirements were less correctly covered by the two diets (101\% PDI for DEA and $97 \%$ for Cracotte) regarding the French PDI system.

\section{DISCUSSION}

\subsection{Intake in relation to silage characteristics}

The two maize silages studied were harvested at the same stage of maturity in order to obtain similar, relatively high DM contents close to $300 \mathrm{~g} \cdot \mathrm{kg}^{-1}$, designed to optimize intake by dairy cows [7].

Maize silages fed by animals were different in cell walls content (NDF) and DM degradability measured in situ. DEA silage had a higher fibre content than Cracotte but a lower DM degradability, the latter difference probably explained by the former. It has been previously observed that the level of NDF would account for $30 \%$ of the variability in DM degradability $(n=160$, $P<0.01 \%$, L'Alliance Élevage, unpublished observations) and the undegradable fraction of NDF is more closely related to the DM degradability value $\left(r^{2}=50 \%\right.$, $r s d=3.5, n=85, P<0.01 \%$; L'Alliance Élevage, unpublished observations). In the current experiment, undegradable NDF was higher for DEA than Cracotte (309 vs. $280 \mathrm{~g} \cdot \mathrm{kg}^{-1}$, respectively) and could appear as an explaining factor of DM degradability.

The small difference in intake of the two silages might be linked to a better DM degradability for Cracotte than DEA. The more quickly degraded a silage in the rumen, the lower the rumen fill and so a shorter residence time is less limiting for feed intake than a less degradable silage [24]. The lower NDF content could explain a shorter residence time in the rumen for Cracotte and with the higher degradability contribute to the enhanced food intake. Mertens [14] showed that the NDF content could explain $58 \%$ of the voluntary DMI for 126 grasses and 61 legumes fed to sheep. This positive relationship between DM degradability and feed intake was already shown in an experiment on dairy cows in early lactation [21]. In this work, feed intake was different among the four groups of dairy cows fed with four different silages ( $400 \mathrm{~g}$ to $1.6 \mathrm{~kg}$ $\mathrm{DM} \cdot \mathrm{d}^{-1}$ ) and differences of DM degradability values were between 0.66 and $5.37 \%$.

\subsection{Feed intake and animal performances}

In this study, an increase of DMI of $650 \mathrm{~g} \mathrm{DM} \cdot \mathrm{d}^{-1}$ was without any significant effect on milk yield, milk composition or weight gain. Small differences were always in favour of the DEA silage for milk production and composition ( $240 \mathrm{~g}$ of milk,

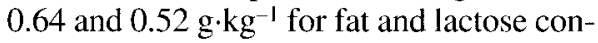
centration, respectively). The additional energy with Cracotte seemed to be used in body weight gain even if the difference was low and not significant between the two silages (0.3 UFL).

The lack of an effect on performance of feed intake of forage with an equal concentrate intake has been observed in previous experiments [2,3]. In the first trial [2], difference of intake of $900 \mathrm{~g} \mathrm{DM} \cdot \mathrm{d}^{-1}$ for the first group was not linked to a better milk production or milk composition but to a better weight gain. In the second trial [3], the first group had a higher feed intake than the second and third group (from 1 to $1.4 \mathrm{~kg} \mathrm{DM} \cdot \mathrm{d}^{-1}$ ) but with the lowest milk yield, milk fat content and weight gain than the overall groups. A better utilization of maize silage could permit an increase of milk yield and/or weight gain or both or any effect. However, some factors linked to experimental protocol or to silages could explain the lack of significant effect of intake of Cracotte on animal performances.

Weight gain was determined by double weighing every 2 weeks and then weight gain was measured for each treatment. This 
measurement was open enough to criticism because it was very linked to numerous variation factors: individual variability of each animal $[5,12]$ and the magnitude of variation could be observed on large time periods (except in early lactation where loss of weight are very important). It is therefore possible to think that in our experiment, its duration was too short in order to diminish this individual variability and to permit a significant difference of weight gain between groups in late lactation.

The lack of an effect of a better feed intake on milk yield could be also due to the low difference of energy consumed by animals ( 0.3 UFL) or explained by the stage of lactation of animals in experiments. They seemed to be less sensitive to a higher intake and therefore gave a lower reply to animal performances.

\section{CONCLUSION}

The conclusions of our study are in agreement with the previous results from Demarquilly and Chenost [6] and Hovell et al. [8], who observed a positive relationship between voluntary intake and digestion rate measured in situ. DM degradability criteria of maize silage seemed to be a good indicator of forage intake although it was not the only one. Nevertheless, it seemed interesting to confirm observations made with a more important number of maize hybrids, with longer experimental periods and cows in different stages of lactation in order to quantify the effect of a higher degradability and then a higher intake on weight gain or on an increase of milk yield.

\section{ACKNOWLEDGEMENTS}

We thank B. Cateland, director of l'Alliance Élevage (Limagrain Rhône-Poulenc), for his financial support and P. Williams, director of the research department of Rhône-Poulenc Animal Nutrition, for his material support.

\section{REFERENCES}

(1) Aufrère J., Utilisation d'enzymes cellulolytiques pour prévoir la digestibilité des fourrages. Bull. Technol. C.R.Z.V. Theix 49 (1982) 23-25.

12] Barrière Y., Emile J.C., Effet des teneurs en grain et de la variabilité génétique sur la valeur énergétique du maïs ensilage mesurée par des vaches laitières, Agronomie 10 (1990) 201-212.

131 Barrière Y., Emile J.C., Traineau R., Hebert Y., Genetic variation on the feeding efficiency of maize genotypes evaluated from experiments with dairy cows, Plant Breeding 114 (1995) 144-148.

14] Blümmel M., Ørskov E.R., Comparison of in vitro gas production and nylon bag degradability of roughages in predicting food intake in cattle, Anim. Feed. Sci. Technol. 40 (1993) 109-119.

[5] Chilliard Y., Rémond B., Agabriel J., Robelin J., Vérité R., Variations du contenu digestif et des réserves corporelles au cours du cycle gestation-lactation, Bull. Technol. C.R.Z.V. Theix 70 (1987) 117-131.

|6] Demarquilly C., Chenost M., Étude de la digestion du fourrage dans le rumen par la méthode des sachets Nylon : liaison avec la valcur alimentaire, Ann. Zootech. 18 (1969) 419-436.

[7] Demarquilly C., Andrieu J., Les fourrages, in : Jarrige R. (éd.), Alimentation des bovins, ovins et caprins, Inra, Paris, 1988, pp. 315-336.

181 Hovell F.D.D., Ngambi J.W.W, Barber W.P., Kyle D.J., The voluntary intake of hay by sheep in relation to its degradability in the rumen as measured in Nylon bags, Anim. Prod. 42 (1986) I11-118.

[9] Jarrige R., Alimentation des bovins, ovins et caprins, Inra, Paris, 1988.

[10] Khazaal K., Dentinho M.T., Ribiero J.M., Ørskov E.R., A comparison of gas production during incubation with rumen contents in vitro and nylon bag degradability as predictors of the apparent digestibility in vivo and the voluntary intake of hays, Anim. Prod. 57 (1993) 105-112.

[11] Kristensen E.S., Moller P.D., Hvelplund T., Estimation of effective protein degradability in the rumen of cows using the nylon bag technique combined with outflow rate, Acta Agric. Scand. 32 ( 1982 ) 123-127.

112] Maltz E., Devir S.. Metz J.H.M., Hogeveen H., The body weight changes in dairy cows as a management aid, Livest. Prod. Sci. 48 (1997) 175-186.

[13] Menke K.H., Steingass H., Estimation of the energetic feed value obtained from chemical analysis and in-vitro gas production using rumen fluid, Anim. Res. Dev. 28 (1988) 7-12.

[14] Mertens D.R., Application of theoretical mathematical models to cell wall digestion and forage intake in ruminants, Ph.D. thesis, Cornell University, Ithaca, NY, 1973. 
[15] Michalet-Doreau B., Vérite R., Chapoutot P., Méthodologie de mesure de la dégradabilité in sacco de l'azote des aliments dans le rumen, Bull. Technol. C.R.Z.V. Theix 69 (1987) 5-7.

[16] Ørskov E.R., McDonald I., The estimation of protein degradability in the rumen from incubation measurements weighted according to rate of passage, J. Agric. Sci. Camb. 92 (1979) 499-503.

[17] Reid R.L., Jung G.A., Thayne W.V., Relationships between nutritive quality and fiber components of cool season and warm season forages: a retrospective study, J. Anim. Sci. 66 (1988) 1275.

[18] Sauvant D., Bertrand D., Giger S., Variations and prevision of the in sacco dry matter digestion of concentrates and by-products, Anim. Feed Sci. Technol. 13 (1985) 7-23.

[19] Statistical Analysis Systems Institute, SASSTAT User's Guide, Version 6, vol. 2, SAS Institute Inc., Cary, NC, USA, 1985.

[20] Tilley J.M.A., Terry R.A., A two stage technique for the in vitro digestion of forage crops, J. Br. Grassl. Soc. 18 (1963) 104-111.
[21] Valentin S.F., Cateland B., Barriere Y., Influence de la dégradabilité de la matière sèche de l'ensilage de maïs mesurée in situ in vivo sur sa consommation par des vaches laitières en lactation, in : Renc. Rech. Ruminants, Paris, 4-5 décembre 1997, 1997, p 95.

[22] Valentin S.F., Williams P.E.V., Forbes J.M., Sauvant D., Comparison of the in vitro gas production technique and the nylon bag degradability technique to measure short and long term processes of degradation of maize silage in dairy cows, Anim. Feed Sci. Technol. 78 (1999) $81-99$.

[23] Van Soest P.J., Symposium on factors influencing the voluntary intake of herbage by ruminants: voluntary intake in relation to chemical composition and digestibility, J. Anim. Sci. 24 (1965) 834.

[24] Van Soest P.J., Nutritional Ecology of the Ruminant, O and B Books, Corvallis, OR, 1982, 373 p. 